\title{
KULT MATKI BOŻEJ W KLASZTORZE OO. KARMELITÓW NA PIASKU W KRAKOWIE I JEGO PROMOCJA W POLSCE
}

\author{
WSTEP
}

Inauguracja Roku Jubileuszowego 600-lecia (1397-1997) sprowadzenia z Pragi do Krakowa pierwszych Karmelitów przez królowę Jadwigę, wymaga określenia ich duchowej specyfiki i prezentacji jako maryjnego zakonu. Zakon w swoim początkowym charyzmacie nawiązywał do stylu życia proroka Eliasza na Górze Karmel i prowadził życie pustelnicze w Palestynie. Po jego przymusowej emigracji do Europy (1238) z powodu inwazji islamu na Palestynę, zakon zmodyfikował swoją regulę, przystosowując ją do nowych warunków życia w Europie. Papież Innocenty IV bullą „Quae honorem" dnia 1 października 1247 r. zatwierdził zmodyfikowaną regułę ${ }^{1}$ Kościół zaś na Soborze Lyońskim II w 1274 r. zaliczył zakon karmelitów do zakonów żebrzących ${ }^{2}$. Pierwotna reguła św. Alberta przestała być ściśle eremicka, choć dopuszczała życie eremickie. Karmelici podejmowali działalność apostolską i studia uniwersyteckie, ale większy nacisk położono na wspólnotowe życie, a szczególnie na kontemplację.

Jan Długosz w swoich rocznikach ${ }^{3}$ i w księdze uposażeń diecezji krakowskiej $^{4}$ pośród istnicjących zakonów w Krakowie, wymienia również karme-

${ }^{1}$ Bullarium carmelitanum. Ed. E. Monsignani et I. A. Ximenes O. Carm. T. 1. Romae 1715 , s. 8-11.

${ }^{2}$ Monumenta Historica Carmelitana. Vol. I. Ed. P. Benedictus Zimmerman. Lirinae 1907, s. 216-217.

${ }^{3}$ J. Dlugosz, Historiae Polonicae libri XII. Wyd. A. Przeździecki. T. 3. Kraków 1876, s. 500; T. M. Trajdos, Fundacja klasztoru karmelitów trzewiczkowych na Piasku w Krakowie. „Nasza Przeszłość”. T. 60:1983, s. 100-103.

${ }^{4}$ Liber beneficiorum dioecesis Cracoviensis. T. 3. Kraków 1864, s. 475. 
litów. Pod rokiem 1395 podaje informacje, że król Władysław Jagielło i królowa Jadwiga rozpoczęli realizować swoją fundację przez budowę klasztoru i kościola pod wezwaniem Nawiedzenia NMP na przedmieściu Piaski i przekazali go braciom zakonu z Góry Karmel. W żywocie zaś biskupa krakowskiego Piotra Wysza, J. Długosz przypisał fundację królowej Jadwidze 5 . Do czasu jej śmierci kościół do połowy był tylko zbudowany. Budowa została ukończona w XV w. z ofiar dobrodziejów, zarówno dostojników państwa, jak również bogatych mieszczan ${ }^{6}$. W $1413 \mathrm{r}$. król Władysław Jagiełło zapisał klasztorowi na utrzymanie 20 grzywien rocznego czynszu, zabezpieczonego na krakowskich żupach solnych Wieliczki i Bochni ${ }^{7}$. Działalność karmelitów nie ograniczała się tylko do przedmieścia Piaski, ale znaczna byla na terenie miasta i w kręgach dworskich. Kościól Nawiedzenia NMP wnet stał się głośny i sławny z krzewienia kultu maryjnego, Bractwa Szkaplerznego i dynamicznego Sanktuarium Matki Boskiej Piaskowej.

\section{Z DZIEJÓW KULTU MATKI BOŻEJ W ZAKONIE KARMELITÓW}

Każdy zakonnik na mocy ślubów zakonnych zobowiązany jest do zachowania reguły i konstytucji zakonu, które określają charyzmat życia braci, istotne elementy życia konsekrowanego, więź z Bogiem i z braćmi, więź z Najświętszą Maryją Panną i zadania apostolskie. Normy prawne ustalane na Kapitułach Generalnych obowiązują zakonników calego zakonu, a uchwały podejmowane na Kapitułach Prowincjalnych obowiązuja zakonników danej prowincji. Normy legislacyjne Kapituł Generalnych, liczne źródła historyczne i cała historiografia karmelitańska świadczą o centralnej pozycji Matki Bożej w życiu zakonu. Ona jest racją jego istnienia, istotnym elementem w życiu duchowym karmelity i forma świętości oraz najdoskonalszym wzorem konsekracji. Całe życie duchowe Karmelu jest dogłębnie maryjne, w swoich poczatkach, nazwie, liturgii, mistyce, kontemplacji i apostolstwie. Stąd średniowieczne zawołanie: "Carmelus totus Marianus est" ${ }^{\text {. }}$.

5 J. Dlugosz, Opera omnia. T. 1, Kraków 1887, s. 420; J. Wyrozumski, Dzieje Krakowa - Kraków do schylku wieków średnich. T. 1, Kraków 1992, s. 485.

${ }^{6}$ J. Wyrozumski, Dzieje Krakowa..., s. 485.

${ }^{7}$ J. Dlugosz, Liber beneficiorum. T. 3. Kraków 1864, s. 476; T. M. Trajdos, Fundacja klasztoru karmelitów..., s. 107.

${ }^{8}$ Albin od Dzieciątka Jezus OCD, Karmel - duch - życie. Kraków 1972, s. 72 (maszynopis). 
1. Kult liturgiczny i paraliturgiczny w Karmelu

Pierwsi karmelici na Górze Karmel zbudowali świątynię na cześć Najświętszej Maryi Panny'. Matkę Bożą czcili jako swoją Patronkę, Królowę, Matkę, Siostrę i Fundatorkę w znaczeniu duchowym ${ }^{10}$. Dla odróżnienia od zakonników sąsiedniego (greckiego) klasztoru św. Małgorzaty, nazywali się „Fratres Beatae Mariae Virginis” lub „Eremitae S. Mariae de Monte Carmelo"11. Nazwa ta w pierwszej wersji przyjęła się w całym zakonie. Po raz pierwszy urzędowo występuje w bulli Aleksandra IV z dnia 15 stycznia 1256 r. $^{12}$. Jedne $\mathrm{z}$ pierwszych konstytucji zakonu opublikowane na Kapitule Generalnej w Barcelonie w 1324 r. na pytanie: dlaczego nazywamy się braćmi Najświętszej Maryi Panny z Góry Karmel? - odpowiadaja: „dając świadectwo prawdzie, mówimy, że następcy Eliasza i Elizeusza zbudowali w tej miejscowości (w pobliżu źródla Eliasza) kościół na cześć Błogosławionej Dziewicy Maryi i wybrali Jej imię jako przydomek, z tego powodu i od tego czasu, z przywileju apostolskiego nazywali się braćmi Najświętszej Maryi Panny z Góry Karmelu"'l3.

Wyrazem wdzięczności i czci dla Matki Bożej były wznoszone liczne kościoły pod Jej wezwaniem. Według katalogu z 1766 r., ogłoszonego przez Garcię Nalachora, spośród 526 świątyń poświęconych Matce Bożej w Zakonie, 293 było pod wezwaniem Najświętszej Maryi Panny z Góry Karmel, 77 p.w. Zwiastowania, 15 p.w. Wniebowzięcia, 14 p.w. M. B. Laski Bożej, 11 p.w. Niepokalanego Poczęcia etc. ${ }^{14}$. Kościoły dedykowane Matce Bożej obdarzone były odpustami zwłaszcza przez papieża Sykstusa IV i Juliusza II ${ }^{15}$.

Od XIII w. obchodzono w Zakonie następujące uroczystości maryjne: Oczyszczenia, Zwiastowania, Wniebowzięcia i Narodzenia NMP. W XIV w. wprowadzono święto Niepokalanego Poczęcia NMP, a od końca XIV w.

9 Citez de Iherusalem z 1220 r. Por. Mon. Hist. Carm. Vol. 1, s. 281; E. Friedman OCD, The latin Hermits of Mount Carm. Roma 1979, s. 160-165.

${ }^{10}$ A. Bostius, De Patronatu et patrocinio Beatissimae Virginis Mariae in dicatum sibi Carmeli Ordinem. W: Daniel a Virgine Maria, Speculum carmelitanum sive historia Eliani Ordinis Fratrum Beatissimae Virginis Mariae de Monte Carmelo. T. 1. Antverpiae 1680, s. 375-431; Joannes Bacon, Tractatus de institutione Ordinis Carmelitani ad venerationem B. Virginis Deiparae. W: Speculum carmelitanum, t. 1, s. 164-165.

${ }^{11}$ L. Saggi O. Carm., Santa Maria del Monte Carmelo. W: Santi del Carmelo. Roma 1972, s. 110; C. Kopp, Elias und Christentum auf dem Carmel. Paderborn 1929, s. 106-122.

${ }^{12}$ Bull, Carm. I, s. 15.

${ }^{13}$ Mon. Hist. Carm. I, s. 20.

${ }^{14}$ Valerius Hoppenbrouwers O. Carm., Devotio mariana in Ordine Fratrum BMV de Monte Carmelo a medio saeculo XVI usque ad finem saeculi XLX. Romae 1960, s. 233; J. Smet O. Carm., The Carmelitas. Romae 1975, s. 24-35.

${ }^{15}$ Bull. Carm. I, s. 428. 
święto Matki Bożej z Góry Karmel, jako pamiątkę i wotum wdzięczności za liczne dobrodziejstwa wyświadczone Zakonowi przez Najświętszą Maryję Pannę $^{16}$. Najpierw wprowadzono je $w$ Anglii. Od 1609 r. obowiazzywało w całym Zakonie, jako święto Matki Bożej Szkaplerznej ${ }^{17}$. 24 września 1726 r. papież Benedykt XIV rozciagnął to święto na cały Kościół katolicki ${ }^{18}$.

W 1564 r. Kapituła Generalna ogłosiła kalendarz liturgiczny, w którym oprócz wymienionych już świąt podaje jeszcze święto Nawiedzenia NMP, Ofiarowania i Matki Bożej Śnieżnej ${ }^{19}$. W 1628 r. Zakon wyjednał u Starszego Apostoła oktawę Matki Bożej Szkaplerznej ${ }^{20}$. Z czasem do kalendarza karmelitańskiego wprowadzono następujące święta maryjne: Imienia Maryi (1665), Świętej Maryi od wykupu niewolników (1696), Zaślubin ze św. Józefem (1699), Matki Bożej Różańcowej (1716), Matki Bożej Bolesnej w piątek po niedzieli Męki Pańskiej (1727), Oczekiwania Narodzenia Chrystusa (1748), Opieki Matki Bożej (1748), Najświętszego Serca Maryi (1814), Siedmiu Boleści Matki Bożej 15 września (1814), Wspomożenia Chrześcijan, Macierzyństwa Bożego, Przeniesienia domku loretańskiego (1817), Wigilia Matki Bożej Szkaplerznej (1828), Wigilia Niepokalanego Poczęcia NMP (1863). Poszczególne prowincje wprowadzały jeszcze święta lokalne (np. MB Milosierdzia, MB Częstochowskiej).

Oprócz powyższych świąt karmelici w każdą sobotę odmawiali oficjum o Matce Bożej i celebrowali mszę, o ile rubryki na to pozwalały. Nawet dhugo utrzymywal się zwyczaj codziennego odprawiania mszy porannej (po prymie) o Matce Bożej, we wszystkich konwentach, gdzie było przynajmniej czterech nowicjuszy ${ }^{21}$ lub kleryków. Reforma gregorianska ograniczyła ten przepis, podajac wytyczne odprawiania mszy wotywnych o Matce Bożej ${ }^{22}$.

${ }^{16}$ Augustinus M. Forcadell O. Carm., Commemoratio solemnis Beatae Mariae Virginis de Monte Carmelo. Romae 1951, s. 71.

${ }^{17}$ Acta Capitulorum Generalium Ordinis Fratrum B.V. Mariae de Monte Carmelo. Ed. Gabriel Wessels O. Carm. T. 2, Romae 1934, s. 20; A. M. Forcadell, Commemoratio solemnis..., s. 75-96.

${ }^{18}$ A. M. Forcadell, Commemoratio solemnis..., s. 94.

${ }^{19}$ Acta Cap. Gen. I, s. 457; V. Hoppenbrouwers, Devotio mariana..., s. 140.

${ }^{20}$ A. M. Forcadell, Commemoratio solemnis..., s. 79

${ }^{21}$ „In quolibet conventu, in quo quattuor saltem sunt novitii, cantabitur quotidie primo mane a novitiis missa in honorem beatae Virginis, cum aliqua devota et brevi laude in fine missae eorum magistro semper assistente. Et post Completorium novitii accedent ante altare Virginis benedictae, ut cantent aliquas laudes devotas", Nicolas Audet, Isagogicon preciosissimis comparandum gemnis, ad reformationem vitae regularis et sanctimoniae patrum Carmeli Montis. Venetiis 1524, s. 8, 4; V. Hoppenbrouwers, Devotio mariana..., s. 98.

${ }^{22}$ Missale Ordinis Fratrum Beatae Dei Genitricis semperque Virginis Mariae de Monte Carmelo. Rub. 5. Romae 1587. 
Konstytucje z 1524 r. polecaly w brewiarzu odmawiać Ave Maria po każdym przepisanym Pater Noster ${ }^{23}$. Nakazywały również pościć we wszystkie wigilie świąt Matki Bożej ${ }^{24}$, przyjmować Komunię św. w Jej święta, oraz zabraniały celebrować mszy i kłaść się do snu bez szkaplerza ${ }^{25}$. Przepisy zakonne zobowiazywały wszystkich zakonników bez wyjątku, aby w każdą sobotę zbierali się w białych płaszczach na kompletę dla odśpiewania przed ołtarzem Matki Bożej antyfony Salve Regina ${ }^{26}$. Modlitwa ta, wprowadzona do Kościoła w 1230 r., została przyjęta przez Zakon w 1260 r. Konstytucje z 1324 r. polecały po każdej godzinie kanonicznej odmawiać Salve Regina z wersetem i modlitwą ${ }^{27}$. Generał Zakonu Jan Chrzciciel Rubeo (Rossi) ułożył rytuał dla tej antyfony, śpiewanej dotychczas w każdą sobotę i wigilie Świąt Matki Bożej ${ }^{28}$. Kapituła w Placencji w 1575 r. poleciła śpiewać Salve Regina przy akompaniamencie organów ${ }^{29}$. $\mathrm{O}$. Rubeo również zabronił spożywania mięsa, nabiału i jaj w wigilie świąt Matki Bożej, a kaznodziejom wielkopostnym polecil głosić kazania o Najświętszej Maryi Pannie w każdą sobotę ${ }^{30}$. Polecenia te w całości aprobowała Kapituła Generalna w Placencji ${ }^{31}$. Ponadto zalecila wszystkim zakonnikom wychodzacym z klasztoru, aby przed wyjściem odmawiali w białych płaszczach w kościele lub w kapitularzu trzy razy Pozdrowienie Anielskie i aby pamiętali o obowiązku uczestniczenia w sobotnim Salve Regina ${ }^{32}$.

Konstytucje z 1593 r. polecały urządzać w drugą niedzielę każdego miesiąca nabożeństwo z kazaniem i procesją dla uczczenia Matki Bożej z Góry Karmel $^{33}$. Konstytucje kongregacji tureńskiej z 1637 r. przypominały, aby zakonnicy wchodząc do celi drugiego zakonnika mówili Ave Maria. Na to pozdrowienie nawiedzany odpowiada Deo gratias $^{34}$. Przypominaly również o noszeniu różańca u pasa, odnawianiu corocznie ślubów w święto Matki Bożej z Góry Karmel i poście we wszystkie środy roku ${ }^{35}$.

${ }^{23}$ Constitutiones Carmelitarum Ordinis BMV... I, 3, 9. Venetiis 1524.

${ }^{24}$ Tamże I, 3, 7.

${ }^{25}$ Tamże.

${ }^{26}$ Nicolaus Audet, Isagogicon..., c. 2, 3; Constitutiones... I, 3, 23. Romae 1586.

${ }^{27}$ Mon. Hist. Carm. I, s. 25; por. T. M. Trajdos, U zarania Karmelitów w Polsce. Warszawa 1993, s. 129

${ }^{28}$ V. Hoppenbrouwers, Devotio mariana..., s. 100.

${ }^{29}$ Acta Cap. Gen. I, s. 518.

${ }^{30} \mathrm{~V}$. Hopennbrouwers, Devotio mariana..., s. 100.

${ }^{31}$ Acta Cap. Gen. I, s. 518.

${ }^{32}$ Tamże.

${ }^{33}$ Constitutiones ... Cremonae 1593, s. 83; Instructiones Fratrum Discalceatorum Ordinis Beatissimae Virginis Mariae de Monte Carmelo. Romae 1932, s. 125.

${ }^{34} \mathrm{~V}$. Hoppenbrouwers, Devotio mariana..., s. 105.

${ }^{35}$ Constitutiones ... I, 10, 4; Cadurci 1637. 
Kontakt karmelu z Maryja jest ustawiczny. Instrukcje nakazuja, aby wizerunek Matki Bożej umieszczano w kaplicach i kapitularzach, w salach rekreacyjnych, w oficynach i celach zakonnych ${ }^{36}$. Trzy razy dziennie należy dzwonić na Anioł Pański, a wszyscy zakonnicy winni odmawiać wtedy wspólnie Pozdrowienie Anielskie. Po nieszporach odmawia się w chórze litanį̨ loretańską. Każdy indywidualnie codziennie mówi różaniec ${ }^{37}$.

Również heraldyka i sfragistyka podkreślają maryjny charakter karmelu. Najstarsze herby zakonu maja w polu postać Niepokalanej z Apokalipsy oraz napis: „Jestem Matką i Ozdobą Karmelu”38. Okrąła pieczéć Kapituły Generalnej przedstawia wyobrażenie Matki Bożej na tronie z Dzieciątkiem Jezus na lewej ręce, obok tronu postacie śś. Eliasza i Alberta, a poniżej sześciu zakonników klęczących przed tronem oraz napis w otoku: „Sigillum Capituli Generalis Ordinis Beatae Mariae de Monte Carmeli' ${ }^{39}$. Również pieczęcie generała mialy zawierać wyobrażenie Matki Bożej z korona gwiazd dwunastu ${ }^{40}$.

\section{Nabożeństwo szkaplerzne}

Należy ono obok różańcowego do najpopularniejszych i najstarszych nabożeństw maryjnych $w$ Kościele. W swej genezie sięga średniowiecza i powstało w Zakonie Braci Najświętszej Maryi Panny z Góry Karmel. Okazją do jego powstania stały się głębokie przemiany struktur samego życia zakonu, który ratując swój byt przed inwazją islamu zmuszony był w 1. 1238-1291 wyemigrować z Palestyny do Europy ${ }^{41}$. Pomimo urzędowego zatwierdzenia reguły i zakonu przez Stolice Apostolską, karmelici w Europie doświadczali wielu niepowodzeń. Wykorzenieni ze swego środowiska i eremickiego sposobu życia, znaleźli się $w$ zupelnie nowych warunkach życiowych pod względem klimatycznym, etnicznym i kulturowym. Inkulturacja ich w Europie była trudna. Najwięcej trudności i przykrości zaznali od duchowieństwa i hierarchii. Uważano ich za intruzów. Dowodzono, że regulę zatwierdził papież tylko dla eremitów na Górze Karmel, a ponieważ w Europie musieli oni nieco zmienić styl życia przepisany w regule, przeto zatwierdzenie papieskie stracilo swą ważność. Nie zezwalano im budować klasztorów ani celebrować Mszy

${ }^{36}$ Instructiones..., s. 125.

${ }^{37}$ Tamże; Regula et Constitutiones Fratrum Discalceatorum Ordinis BMV de Monte Carmelo. Romae 1928, s. 24.

${ }^{38}$ Constitutiones Fratrum B. M. de Monte Carmelo (Jana Soretha). Hispali 1573.

${ }^{39}$ Acta Cap. Gen. I, s. 378.

${ }^{40}$ Regula et Constitutiones...; s. 127.

${ }^{41}$ B. J. Wanat OCD, Zakon Karmelitów Bosych w Polsce, Klasztory karmelitów i karmelitanek bosych 1605-1975. Kraków 1979, s. 23. 
św. W tej beznadziejnej sytuacji, jak podaje kronika Wilhelma de Sanvico, Matka Boża objawiła się św. Szymonowi Stockowi (1165-1265), przełożonemu generalnemu zakonu, polecając mu udać się z prośbą o pomoc do papieża Innocentego $\mathrm{IV}^{42}$. Posłuszny Jej poleceniu Szymon zwrócił się do Ojca św. Papież przychylając się do jego prośby wydał w Perugii, dnia 13 stycznia 1252 roku drugi list ${ }^{43} \mathrm{w}$ obronie karmelitów, skierowany do wszystkich arcybiskupów i biskupów, z poleceniem, aby nie robili trudności tym zakonnikom w Europie ${ }^{44}$.

To objawienie się Matki Bożej św. Szzymonowi Stockowi stało się cezurą i momentem zwrotnym $w$ dziejach zakonu. Zaczał się on szybko rozwijać liczbowo i jakościowo. Szymon Stock wprowadził karmelitów do miast uniwersyteckich: Cambridge (1247), Oxfordu (1253) i Bolonii (1260). W latach 1247-1300 założono w Belgii 9 nowych klasztorów, 17 w Niemczech, 27 w Anglii i 16 we Francji.

Wizja św. Szymona opisana przez wspólczesnego jej kronikarza Wilhelma de Sanvico jest prawdopodobnie wizją Szkaplerza św. Późniejsze dokumenty opisujące wizję szkaplerzną odnoszą się do tych samych okoliczności, o których wspomina Wilhelm de Sanvico. Najstarszy katalog świętych zakonu (pocz. XIV w.), wspominając o Szymonie Stocku, podaje przebieg wizji szkaplerznej, który powtarzać się będzie jako stereotyp w późniejszych relacjach ${ }^{45}$. Św. Szymon Stock przełożony generalny w trudnej sytuacji swego zakonu zwraca się z ufnością o ratunek do Królowej i Matki Karmelu. Jego modlitwą sq̨ słowa hymnu do dziś śpiewanego w karmelu - Flos Carmeli, który w przekladzie brzmi:
Kwiecie Karmelu,
Wonna Winnico,
Ozdobo niebios,
Matko - Dzicwico,
- O najwspanialsza!
Matko łagodna,
Czysta i wierna,
Dzieciom Karmelu,
Bądź milosierna,
o Gwiazdo morza! $!^{46}$

Pewnego dnia, w czasie tej modlitwy, objawiła mu się Matka Boża i ukazując szkaplerz (wierzchnią część habitu karmelitańskiego) powiedziała: „To

${ }^{42}$ Chronica Gulielmi de Sanvico, eremitae montis Carmeli, de multiplicatione Religionis Carmelitarum per provincias Syriae et Europae, et de perditione monasteriorum Terrae Sanctae. „Anal. Ord. Carm.” 3:1914-1915, s. 307.

${ }^{43}$ Pierwszy list w obronie karmelitów pap. Innocenty IV wydał 26 lipca 1248 r. Zob. Bull. Carm. I, s. 7-8.

44 „Anal. Ord. Carm." 2:1911-1913, s. 128.

${ }^{45}$ B. M. Xiberta O. Carm., De visione Sancti Simonis Stock. Romae 1950, s. 84-105.

${ }^{46}$ Tamże, s. 283. 
będzie dla ciebie i wszystkich karmelitów przywilejem, kto w nim (szkaplerzu) umrze, nie zazna ognia wiecznego",47.

Miejsce i date wizji szkaplerznej trudno ustalić na podstawie istniejących źródeł. Bardzo stara tradycja wskazuje na klasztor w Aylesford (Anglia), a czas objawienia ustala na 16 lipca $1251 \mathrm{r}^{48}$

Do przywileju szkaplerza św. dodany został nieco później przywilej sobotni, ogłoszony na polecenie Matki Bożej przez papieża Jana XXII w bulli sobotniej, dnia 3 marca $1322 \mathrm{r}^{49}$ Przywilej ten polega na obietnicy Matki Bożej wybawienia z czyśca w sobotę po śmierci tych, którzy nosili pobożnie szkaplerz, zachowywali czystość według swego stanu i odmawiali oficjum o Matce Bożej (jeśli nie umieli czytać, to zachowywali post w środy i soboty). $\mathrm{Z}$ powodu braku pewnych i bezpośrednich przekazów źródłowych $\mathrm{w}$ formie relacji ze strony samego św. Szymona Stocka, jak i współczesnych mu świadków, historyczność wizji szkaplerznej i bulli sobotniej stała się od XVIII w. przedmiotem wielu dyskusji, krytyki i polemik ${ }^{50}$. W tej sytuacji, popularne nabożeństwo szkaplerzne więcej opiera się na Magisterium Kościola oraz racjach teologicznych, niż na przesłankach i dokumentacji historycznej.

Kościół wielokrotnie zatwierdzał przywileje szkaplerza i popieral nabożeństwo szkaplerzne. Ustanowił święto Matki Bożej Szkaplerznej jako wspomnienie Najświętszej Maryi Panny z Góry Karmel w dniu 16 lipca. Papież Klemens VII bulla „Ex clementi” z dnia 12 sierpnia $1530 \mathrm{r}$. potwierdził wszystkie laski i przywileje Zakonu Karmelitańskiego. Na mocy apostolskiej władzy zatwierdzil przywilej sobotni („a dla pewności, gdyby nigdy nie był udzielony, przez te bulle niech będzie udzielony"sl). Przywileje szkaplerzne potwierdzili również inni papieże: Paweł II w 1534 i w 1539 r., Pius V w 1564 r., Grzegorz XIII w 1577 r., Paweł V w 1613 r., Klemens X w 1637 r., Pius XI w 1922 r.

${ }^{47}$ Bartłomicj Xiberta zebrał 16 wariantów sformułowań wypowiedzi Matki Bożej na określenie przywileju szkaplerznego. Po ich krytycznej analizie ustalił, że Jej autentycznymi słowami sa: „Hoc erit tibi et cunctis Carmelitis Privilegium, quod in hoc moriens aeternum non patietur incendium". - Zob. De visione S. Simonis Stock. Romae 1950, s. 173-175.

${ }^{48}$ A. M. Forcadell OC, Commemoratio solemnis Beatae Mariae Virginis de Monte Carmelo. Romae 1951, s. 12.

${ }^{49}$ Transuptum authenticum Bullae Sabbatinae. W: „Anal. Ord. Carm." 4:1917-1922, s. 251-260; Ludovico Saggi, La Bolla Sabbatina. Ambienti festo et tempo. Roma 1967. Zaginął oryginał bulli sobotniej Jana XXII. Późniejszy jej odpis budzi poważne zastrzeżenia co do jego autentyczności. - Zob. L. Saggi, La Bolla Sabbatina..., s. 27.

${ }^{50}$ Zob. B. M. Xiberta, Annotationes circa statum quaestionis de sacro Scapulari. Romae 1940, s. 11-31; tegoż, De visione S. Simonis Stock. S. 31-78; H. M. Esteve O. Carm., De valore spirituali devotionis s. Scapularis. Romae 1953, s. 67-99.

${ }^{51}$ Bull. Carm. II, s. 47-50; Bulla Clementis VII 12 Aug. 1530. „Anal. Ord. Carm.” 4:1917-1922, s. 269-274. 
Do dalszego rozwoju i pogkebienia nabożeństwa szkaplerznego w ogromnej mierze przyczynił się papież Pius XII. Z okazji 700-lecia szkaplerza karmelitańskiego (1251-1951) wystosował on apostolski list $z$ dnia 11 lutego 1950 r., słusznie nazwany „magna charta” nabożeństwa szkaplerznego. Stwierdził on: „Z pewnością nikomu nie jest tajnym, jak wiele przyczynia się miłość ku Najswiętszej Maryi Pannie do ożywienia katolickiej wiary i poprawy obyczajów, szczególnie dzięki tym formom nabożeństwa, które zdają się posiadać wyższą ponad inne moc oświecania umysłów niebieską nauką i zapalania dusz do doskonalenia chrześcijańskiego życia. Najpierw należy do nich zaliczyć nabożeństwo szkaplerza karmelitańskiego, które przez swoja prostotę, stosując się do pojęcia każdego człowieka, rozpowszechniło się bardzo szeroko wśród wiernych chrześcijan, przynosząc zbawienne owoce. [..] Nie chodzi tu bowiem o rzecz małej wagi, lecz o zdobycie wiecznego zbawienia według obietnicy podanej przez Najświętsza Maryję Pannę. Chodzi tu o najdonioślejsza sprawę dla każdego i o właściwe jej przeprowadzenie. Bez wątpienia szkaplerz jest niejako świętą szatą (habitem) maryjna, znakiem i gwarancją opieki Bożej Rodzicielki..."52.

Ojciec św. Pius XII przedstawia szkaplerz jako szate maryjna, jako znak i dowód opieki Maryi, jako: wezwanie do intensywnego życia wewnętrznego, pamiątkę otrzymaną od Najświętszej Matki, zwierciadło pokory i czystości, wezwanie do skromności i prostoty oraz jako szczególne zobowiązanie do poświęcenia się Niepokalanemu Sercu Maryi.

Z okazji jubileuszu 700-lecia Szkaplerza św. odbył się w Rzymie od 5 do 9 sierpnia 1950 r. Międzynarodowy Kongres Szkaplerzny Zakonu Karmelitańskiego. Brało $\mathrm{w}$ nim udział ponad 10.000 uczestników $\mathrm{z}$ całego świata. 6 sierpnia Pius XII przyjął na audiencji w Bazylice św. Piotra uczestników Kongresu, podkreślając $\mathrm{w}$ swoim przemówieniu znaczenie nabożeństwa szkaplerznego. Między innymi powiedział: „Uplywa trzeci tydzień, jak zawitała pierwsza jutrzenka siedemsetnej rocznicy od 16 lipca $1251 \mathrm{r}$., daty pamiętnej nie tylko dla Karmelu i wszystkich jego czlonków. W rzeczywistości, ileż dusz od tego dnia zawdzięcza - nawet w sytuacjach beznadziejnych - swoje ostateczne nawrócenie i swoje wieczne zbawienie szkaplerzowi, którym były odziane! Iluż to ludzi dzięki niemu doznało w niebezpieczeństwach ciała i duszy Macierzyńskiego wspomożenia Maryi! Nabożeństwo szkaplerzne sprowadza na świat potężny strumień łask duchowych i doczesnych"s3.

We wszystkich klasztorach karmelitańskich na całym świecie odbyły się uroczyste nowenny, tridua i akademie ku czci Matki Bożej Szkaplerznej. Tysiące wiernych przyjmowało karmelitański szkaplerz. Uroczystości centralne

\footnotetext{
52 "AAS”. 42:1950, s. 390

53 "Glos Karmelu", nr 7-8:1951, s. 162.
} 
zakończone zostały przeniesieniem relikwii św. Szymona Stocka z Francji do Anglii, na domniemane miejsce wizji szkaplerznej w Aylesford. $Z$ tej okazji Papież Pius XII w liście do przełożonego generalnego Kiliana Lynch napisał: „Przesylamy Ci Drogi Synu i wszystkim dzieciom rodziny karmelitańskiej nasze ojcowskie życzenia, niejako hymn pochwały i podziękowania za tak piękne uroczystości, które im bliżej końca, tym były bardziej imponujące.

Jak delikatny powiew fal, które muskaja brzegi Kentu będzie ten hymn śpiewany przez wiernych całej kuli ziemskiej, wpisanych do karmelitańskiego szkaplerza, otoczonych opieką Matki Bożej, aby łatwiej iść śladami Jej Syna Jezusa. Ten hymn uroczysty na cześć Dziewicy będzie się roznosił w akordach jeszcze słodszych i natchnionych po świętych ziemiach Aylesford, jako dalszy ciag anielskicj symfonii przerwanej przez cztery wieki" ${ }^{54}$.

Sobór Watykański II w Konstytucji dogmatycznej o Kościele napomina „wszystkich synów Kościola, aby szczerze popierali kult Błogosławionej Dziewicy, szczególnie liturgiczny, a praktyki i zbożne ćwiczenia ku Jej czci zalecane $\mathrm{w}$ ciagu wieków przez Urząd Nauczycielski cenili wysoko i to co postanowione było w minionych czasach o kulcie obrazów Chrystusa, Błogosławionej Dziewicy i Świętych, pobożnie zachowywali" ${ }^{55}$. Papież Paweł VI w apostolskim liście do kard. Silva Enriquez, arcybiskupa Santiago w Chile, przeznaczonym na otwarcie obrad Kongresu Mariologicznego Santo Domingo, interpretując powyższe słowa Konstytucji o Kościele o zalecanych praktykach w ciągu wieków przez magisterium Kościoła na cześć Matki Bożej, wyraźnie stwierdza, że powyższe słowa są aluzją do Różańca i Szkaplerza Karmelitańskiego $^{56}$.

Szkaplerz jest zewnętrznym znakiem konsekracji - poświęcenia i oddania wlasnego życia Matce Bożej według ducha i ascezy Karmelu. To poświecenie prowadzi do pełnego zawierzenia się Jej opiece oraz do rozwijania kultu i naśladowania Jej wzniosłych cnót. Prowadzi do poznania Jej roli w ekonomii Odkupienia, Jej życia duchowego, zjednoczenia z Chrystusem i Kościołem. Prawdziwa miłość do Maryi prowadzi do udziału w miłości odkupieńczej i oblubieńczej Chrystusa. W pobożnych praktykach nie ogranicza się tylko do noszenia szkaplerza, ale do codziennej rozmowy z Niebieską Matką przez odmawianie Różańca św., tak bardzo zalecanego przez Niepokalaną w Lourdes i Fatimie. Sama Matka Boża zdaje się podkreślać znaczenie i korelację tych praktyk i nabożeństw, gdyż objawienia w Lourdes zakończyly się w święto Matki Bożej Szkaplerznej. Z tego tytułu św. Bernadetta nosila szkaplerz do końca życia. Objawienia zaś w Fatimie zakończyły się wizją Matki Bożej

\footnotetext{
54 ,AAS". 43:1951, s. 589-590.

${ }^{55}$ Lumen Gentium, nr 67.

56 „AAS". 57:1965, s. 376-377.
} 
Szkaplerznej. Z tej też racji uprzywilejowana Lucja wstapila do klasztoru ss. Karmelitanek Bosych pouczając, że w posłannictwie Matki Bożej Fatimskiej „Różaniec i Szkaplerz sa nierozdzielne" ${ }^{357}$.

Nabożeństwo szkaplerzne urzeczywistnia się w Karmelu przez przynależność do Bractwa Szkaplerznego. Osoby świeckie przez przyjęcie szkaplerza (symbol maryjnego habitu) i zapisanie się do Bractwa uczestnicza w duchowości i przywilejach zakonu karmelitańskiego. Wyraźnie to stwierdza Pius XII: „Wszyscy zatem Karmelici, czy to w zamknięciach pierwszego lub drugiego zakonu, czy to w trzecim zakonie regularnym lub świeckim, czy wreszcie w Bractwach żyjąc zespoleni węzłem miłości, przynależą do jednej rodziny Matki Najświętszej, niech zachowują w wiecznej pamięci wzór pokory i czystości Najświętszej Dziewicy, a w prostym kroju tej szaty upatrują streszczenie cnót skromności i prostoty. Niech tẹ szatę, którą dzień i noc się okrywaja, uważaja za wymowny symbol modlitwy, którą błagają Boga o pomoc"s8.

Początki bractwa sięgają XIII w. Od czasu objawienia się Matki Bożej św. Szymonowi Stockowi i nadania wielkich przywilejów szkaplerzowi karmelitańskiemu, rozpoczął się masowy rozwój tego bractwa. W XIV w. powstały pierwsze bractwa szkaplerzne we Florencji, Bolonii, Wenecji i innych miastach. W krótkim czasie erygowano je przy wszystkich klasztorach karmelitańskich. Stanowily one jedną z form działalności zakonu.

\section{Maryja w życiu duchowym Karmelu}

Karmelici widzieli w Maryi Matkę, dającą życie karmelowi, który całkowicie do Niej należy. Ponieważ Jej kult jest racją istnienia zakonu, dlatego Maryja zasługuje na tytuł Matki Karmelu. Według przekonania tradycji Maryja zrodziła karmel. Daje mu życie. Najpierw podaje mu swoje własne, jako wzór do naśladowania i ideal do osiaggnięcia. Następnie wiara dzieci karmelu w misję i rolę swej Matki pełnej łaski i Matki życia Bożego, pozwala zrozumieć to duchowe macierzyństwo w calym jego programie. Świadomość Jej roli w ekonomii odkupienia, tajemnicy Chrystusa i Kościoła prowadzi do głębokiej zażyłości ze swą Matką i Siostrą w Karmelu. Karmelici rozumiejąc, że duchowe macierzyństwo Maryi rozciąga się na cały porządek łaski Bożej, z potrzeby więc serca doszli do calkowitego poświęcenia i oddania się Maryi, a przez Maryje Bogu. Dokonywało się to przez uroczysty i publiczny akt profesji zakonnej. Pierwotna formuła z konstytucji Kapituły Londyńskiej

${ }^{57}$ La Madonna del Carmine e lo Scapulare. Firenze, s. 18.

58 „AAS”. 42:1950, s. 390. 
z 1281 r. przepisywała, aby nowicjusz ubrany w tunikę złożył swoje ręce w ręce przeora klasztoru i wypowiedział słowa:

„Ja, NN, składam swoja profesje i przyrzekam posłuszeństwo Bogu

i Błogosławionej Dziewicy Maryi z Góry Karmel i Przełożonemu

Generalnemu Braci Zakonu Najświętszej Maryi z Góry Karmel, według reguły i konstytucji tychże Braci aż do śmierci",59.

W powyższym akcie profesji Maryja jest wymieniona jako osoba, której składa się śluby i jako Patronka Karmelu. Przez profesję karmelita poświęcal się na służbę Maryi, oddawał się Jej na własność, ofiarowując w darze swoje życie z obowiązkiem czci i służenia Jej z pokorą. Taką interpretację znajdujemy w liście przełożonego generalnego Bernarda Oreliusza do papieża Urbana VI z $1376 \mathrm{r}^{60}$, w obronie maryjnego charakteru zakonu oraz $\mathrm{w}$ pismach karmelitańskich teologów: Jana Baconthorpa $(\dagger 1346)^{61}$, Jana z Hildesheim $(† 1370)^{62}$, Jana Grossiego ${ }^{63}$, Jana Paleonidorusa ${ }^{64}$, a szczególnie Arnolda Bostiusza ( $\uparrow 1499)$, popularnego humanisty i wybitnego znawcy tradycji i historii Karmelu. W swoim traktacie „De patronatu et patrocinio Beatissimae Virginis Mariae in dicatum sibi Carmeli ordinem" $" 65$ pozostawil praktyczne wskazania

${ }^{59}$ Forma professionis. Novitius indutus tunica, sine capucio, ponat manus suas inter manus prioris et dicat: „Ego frater NN facio professionem et promitto obedientiam Deo et Beatae Mariae et tibi frater N Priori generali fratrum heremitarum Ordinis Beatae Mariae de Monte Carmelo tuisque successoribus secundum regulam et constitutiones predictorum fratrum usque ad mortem". Por. Constitutiones Capituli Londinensis anni 1281. Ed. Ludovicus Saggi. „Anal. Ord. Carm.” 25:1950, s. 229.

${ }^{60}$ Informatio Bernardi Olerii. Zob. Spec carm. t. 1. Antverpiae 1680, s. 170

${ }^{61}$ Karmelici byli żarliwymi obrońcami dogmatu Niepokalanego Poczęcia NMP. Franciszek di Buona Speranza cytuje 126 autorów karmelitanskich (w XV w. było ich 160) broniących Niepokalanego Poczęcia NMP. Do najsławniejszych należał Jan Chrzciciel Mantuanus, Arnold Bostiusz i Jan Baconthorp (†1346). Ten ostatni oprócz traktatów teologicznych napisał: 1) Compendium historiarum et jurium pro defensione institutionis, confirmationis, et institulationis Ord. B. Virginis Mariae de Monte Carmelo, 2) Tractatus de institutione Ordinis Carmelitani, ad venerationem Beatae Virginis Dei-Parae. zob. Bibl. Carm. I, s. 743-753; Gabriel ab Annuntiatione OCD, De fide in Immaculatam Conceptionem apud Carmelitas usque ad saeculum XVI. „Anal. Ord. Carm." 5:1930, s. 31-44, 81-87.

${ }^{62}$ Defensorium Ord. Fratrum Dei Genetricis Mariae de Monte Carmelo Zob. Spec. carm. I, s. 145-159.

${ }^{63}$ Viridarium Ordinis B. V. Mariae de Monte Carmelo. W: Spec. carm. Venetiis 1507, s. 100-102; Gratianus a s. Teresia OCD, Viridarium Joannis Grossi. Ephem. Carmeliticae. $7: 1956$, s. $240-284$.

${ }^{64}$ Obrońca Niepokalanego Poczęcia NMP. Zmarł w 1507 r. Autor licznych traktatów teologicznych, między innymi: „De puritate Conceptionis B. V. Mariae” oraz "Contra Wigandum, pro Abbate Trithemio". Zob. Spec. Carm. I, s. 220-273.

${ }^{65}$ Spec. carm. I, s. 375-431; P. Gabriel de S. M. Madeleine, Mater Carmeli. Romae 1931; tenże, La consecratione totale a Marianel „De patronatu Mariae" di Arnoldo Bostio, 
do całkowitego oddania się Maryi przez szkaplerz i konsekrację zakonną, praktykowane dzień po dniu, wśród ukrytych malych spraw codziennego życia.

W pierwszym rozdziale swego traktatu Bostiusz zachęca i przynagla współbraci, aby odpowiedzieli na miłość Maryi sposobem życia i formą kultu, w którym znajdą się istotne elementy pełnego Jej poświęcenia się i oddania ${ }^{66}$. Harmonijną syntezę św. Ludwika M. Grigniona de Montford „Wszystko przez Maryję, z Maryja, w Maryi i dla Maryi" ${ }^{\prime 67}$ odnajdujemy w doktrynie Arnolda Bostiusza i jego żarliwych wezwaniach do miłowania Matki Bożej, skierowanych do współbraci. Zachęca on ich do odpowiedzi na miłość Maryi, naszą miłością, która rozpali się przy kontemplowaniu Jej piękna, do Jej naśladowania i całkowitego uzależnienia się od Maryi ${ }^{68}$.

\section{a) Miłować Maryję}

Za niezmierzona miłość Matki Bożej - pisze Bostiusz - „,spróbuj karmelitański Bracie okazać się dla Niej dobrym bratem. Nie zapominaj nigdy o szczodrobliwości i uczuciach, które wytryskają z Jej serca, zawsze jednakowe i silne, oraz zobacz z jaką obfitością wzajemnej miłości powinieneś Ją uścisnąć, odwdzięczając się za Jej miłość. Najpiękniejsza na wszystkie sposoby i w swojej niezgłębionej - miodoplynnej słodyczy oraz w swojej urodzie (wdzięku). Jest cudem piękności, który fascynuje wszystkich, mając najpiękniejszego Malarza wszechświata, który udzielił Jej wszystkich swych barw"69. „Pragnę kochać Ją wzajemnie! Bez Niej nie potrafię żyć!"”o

\section{b) Naśladować Maryję}

Powodem dla którego karmelita więcej, niż ktokolwiek inny powinien naśladować Maryję jest więź braterstwa, która z Nią go lączy: „Przyjmij, najmilszy synu, szkaplerz twego zakonu, jako znak braterstwa..." - powiedziała Matka Boża do św. Szymona Stocka, podając mu szkaplerz. Bostiusz uczy:

Carmelitano del quatrocento". W: Vita Carmelitana - Rivista di cultura spiritale. Roma, Maggio 1941, s. 65-95.

${ }^{66}$ Tamże, s. 379.

${ }^{67}$ O doskonalym nabożeństwie do Najśw. Maryi Panny. Poznań 1927; tegoż, Tajemnica Maryi. Poznań 1946.

${ }^{68}$ A. Bostius, De Patronatu..., s. 1534.

69 Tamże.

${ }^{70}$ Tamże. 
„Okaż śmiało ten twój związek z Nią, podobieństwem obyczajów... Nie czyń niczego, co by było niegodne takiej Siostry... Nie bądź wyrodnym synem w relacji do twojej najlepszej Matki i Siostry. Szlachetnym postępowaniem twojego życia okaż swoje pochodzenie. Brat - w obecności najwyższej godności swej Królowej Maryi nie odważy się na postẹpowanie niegodziwe, mając tak wielką Siostrę. Natomiast podobieństwem obyczajów daj skuteczny znak twojego z Nią związku. Jeśli jest prawda, że nigdy nikt nie dorównał Jej, ani nie dorówna Jej cnocie, to jednak wszyscy moga iść Jej śladami" "71.

Karmelita znajduje w Maryi doskonałe urzeczywistnienie swojego ideału kontemplacyjnego. Samotność i milczenie należą do ważnych elementów duchowości zakonu. Każdy karmelita powinien ukierunkować się na Maryję, przeglądać się jak w zwierciadle w Jej nieskalanej czystości, w Jej milczeniu i skupieniu. Naśladowanie Maryi nie ogranicza się tylko do jakiegoś szczegółu lub momentu, ale rozciaga się na całe Jej życie, na Jej postawe wewnętrzna wobec Boga i ludzi, na Jej duchowe przymioty ${ }^{72}$.

\section{c) Zależność od Maryi}

Zależeć od Maryi, to znaczy urzeczywistniać całkowitą uległość wobec Matki Bożej na podobieństwo malego dziecka, przez zawierzenie Jej swojego życia. Wypływa to z prawdy o powszechnym wstawiennictwie, pośrednictwie i duchowym macierzyństwie Maryi: „Oto Matka twoja” (J 19, 27). Wszystkie łaski otrzymujemy od Boga przez Maryję, a nasze niedoskonale czynności ludzkie nabierają wartości, o ile Ona przedstawia je Bogu. Dlatego należy utrzymywać łączność z Maryją przez ustawiczna pamięć i modlitwę. Modlitwa powinna być rozmowa pelną miłości dziecka ze swoją Matką, wewnętrznym spotkaniem: „Uczcij Ja poselstwem Trójcy Świętej (Ave Maria), a będzie to jakbyś uściskał swoją Matkę"73.

W ciągu całego dnia pamięć o Maryi powinna przenikać serce i umysł karmelity: „Pełna miłości pamięć o Niej niechaj ci towarzyszy we dnie i w nocy, podczas twoich ćwiczeń, twoich prac i rozmów; w pośród Twoich radości, w twoich smutkach i w twoim spoczynku. Niech Ona zajmuje pierwsze miejsce w twojej pamięci”. I zaraz dodaje: „Jakąkolwiek rzecz chcesz ofiarować Bogu, powierz ją rękom Maryi. Ona troskliwie będzie dbać o sprawy swojego brata".

${ }^{71}$ Tamże, s. $1535-1536$.

${ }^{72}$ B. J. Wanat OCD, Ewa Stolarczyk, Szkaplerz znakiem oddania się Maryi. Czerna 1994, s. 35.

${ }^{73}$ Speculum carmelitanum I, s. 379. 
Gdy się żyje w zależności i oddaniu Maryi, postęp duchowy jest pewniejszy: „co dzień będziesz stawał się większy, bardziej oświecony, bardziej wewnętrzny, czystszy i silniejszy: jednym słowem, staniesz się lepszym, ponieważ Ona uczy dróg Bożych" "74.

Nabożeństwo do Matki Bożej według nauki o. Arnolda Bostiusza jest $z$ istoty swojej wewnętrzne, obejmujące i poddające całe życie duchowe świathu i wplywom Maryi. Znajdują się więc w nim wszystkie elementy życia całkowicie poświęconego Maryi.

W oparciu o całą tradycję karmelitańską i naukę o. Bostiusza prawdziwy rozkwit i apogeum doktryny maryjnej nastapil w XVII wieku, w lonie Reformy Tureńskiej Karmelu. Znacznie przyczyniła się do tego rozwoju Siostra Maria od św. Teresy Petyt (1623-1677), flamandzka tercjarka karmelitańska, obdarzona przez Boga mistycznymi łaskami i darem kontemplacji ${ }^{75}$. Prowadzila ona $w$ Malines życie pustelnicze $z$ kilkoma towarzyszkami. Jej kierownikiem duchowym był slawny o. Michał od św. Augustyna van Ballaert (16211684), karmelita z Reformy Tureńskiej. W Gandawie wydal jej biografię wraz notatkami duchowymi dotyczącymi życia w Maryi, dla Maryi i z Maryja w Bogu, pozostawione przez penitentkę ${ }^{76}$. Opisał w niej klasyczne etapy jej życia duchowego, zwłaszcza bierną noc ducha, która trwała ok. 5 lat. U wyjścia z tej nocy bezpośrednio przed zaślubinami duchowymi, opisuje „świetlany wyłom" - wspaniały okres, który sama pustelnica nazywa Życiem Maryjnym w zjednoczeniu z Maryja w Bogu. Jest to nadzwyczajna łaska Boża, aby duszę doprowadzić do doskonalszego zjednoczenia i zaślubin duchowych.

O. Michał od św. Augustyna opublikowal również traktat „O życiu na wzór Maryi, Maryjnym w Maryi i przez Maryje" "77. Autor w formie teologicznego wykładu porzadkuje i przedstawia doświadczenia duchowe s. Marii od św. Teresy i swoje wlasne. Uczy on jak należy się zachowywać, gdy Duch Święty nie udziela duszy duchowej czułości życia maryjnego; wówczas należy ograniczać się do przyjmowania Bożych inspiracji i poruszeń. „Ten sposób miłowania Najświętszej Dziewicy jest sposobem doskonałym, najczystszym i najlepszym ze wszystkich. Zdaje się jednak, że doświadcza go niewielka liczba dusz. Życie bowiem maryjne w Maryi i dla Maryi i zarazem boskie w Bogu i dla Boga, zdaje się być rzeczywiście zarezerwowane i udzielane za szczególną łaską jedynie duszom, obdarzonym wyjątkową miłością dla Maryi, dzieciom umiłowanym, których Ona sobie sama wybiera".

\footnotetext{
${ }^{74}$ Tamże, s. $416-417$.

${ }^{75}$ B. J. Wanat OCD, Ewa Stolarczyk, Szkaplerz..., s. 37.

${ }^{76}$ Hetleven vande Weerdighe Moeder Maria a Sta Teresia Petyt. Gent 1683.

${ }^{77}$ De vita Mariae-formi et Mariana in Maria propter Mariam. Antverpiae 1671
} 
Oto niektóre wyjątki z nauki i doświadczeń o. Michała od św. Augustyna i s. Marii od św. Teresy:

„Życie maryjne - to życie w Maryi, z Maryja i dla Maryi - czerpie cala swa godność, szlachetność, wzniosłość i doskonałość ze ścisłego zjednoczenia z Bogiem, jakim cieszy się Najświętsza Dziewica oraz z nadobfitości i uczestnictwa w laskach i doskonałościach Bożych, udzielonych Jej bez miary.

Laska Boża daje mi ponadto doświadczyć, że można praktykować to życie w Maryi, z Nią i przez Nią, a zarazem w Bogu, dla Niego, z Nim i w Nim, prawie $z$ taka samą prostota, głębia, oderwaniem ducha, jak życie w samym i czystym Bóstwie. Dochodzi do tego, że w tych chwilach pozostaje w duszy bardzo mało wyobrażeń osoby Maryi, gdyż dusza umiała dostrzec Ją tak bardzo zjednoczona z Bogiem i w Bogu.

Nadprzyrodzone życie duszy w Maryi, dla Niej, z Nią i przez Nią trwa dalej i wzrasta do większej doskonałości i stałości. To czego tu zaznaję, czego doświadczam i odczuwam, jest szczególne i prawdziwe; z mojej strony nigdy nic takiego nie slyszałam, ani nie czytałam.

Wydaje mi się, rzec można, że ta najmilsza Matka jest życiem mej duszy, a zatem duszą mej duszy, a to dla tej przyczyny, że wydaje i rodzi życie duszy w Bogu, czyli życie Boże, w sposób bardzo oczywisty, z którego dobrze zdaję sobie sprawę. Dzieje się to przez dostrzegalny przypływ lask działających, uprzedzających, umacniających, pobudzających i zachęcających, łask, które towarzysza, następują i prowadzą dalej, które pomagają wytrwać w tym życiu z Bogiem z większą siłą, stałością, czystością itd." (Maria od św. Teresy) ${ }^{78}$.

O. Michał od św. Augustyna streszczając wypowiedzi swej penitentki zauważa: „Dusze, które osiagnęly ten stopień milości, zdają się doświadczać głębiej jeszcze tego życia maryjnego: stwierdzaja one, że można się ćwiczyć w tym życiu maryjnym, w Maryi, dla Niej i z Nia, a zarazem w Bogu, dla Boga i przez Niego, prawie z taka samą prostota, głębią i skupieniem ducha, jak proste życie Boże, którego jedyny przedmiot stanowi Bóstwo. To życie maryjne dalekie jest od stawiania jakiejkolwiek przeszkody życiu duchowemu, ale jest raczej wielką pomoca. Maryja służy duszy jako środek i ściślejszy węzeł zjednoczenia $z$ Bogiem $\mathrm{i}$ daje $\mathrm{w}$ ten sposób duszy milującej oparcie i pomoc, które pozwalają jej osiagnąć i dalej prowadzić życie kontemplacyjne, jednoczące i przekształcające w Boże z większą stałościa, wytrwałością i doskonałością. Jest to prawda, chociaż ta kontemplacja maryjna, te czule nachylenia $\mathrm{i}$ inne działania miłości względem Maryi moga się czessto wydawać bardzo zmieszane $z$ władzami zmysłowymi i ich działaniem. Kiedy jednak pocho-

${ }^{78}$ O. Jan od Jezusa Hostii OCD, Matka Pięknej Milości. Przeklad M. Teresy od Niep. Serca Maryi - Anny Czarneckiej OCD, książki "Notre Dame de la Montée du Carmel". Tarascon 1951 (maszynopis), s. 186-188. 
dzą z głębi duszy i dokonują się niejako samorzutnie pod wpływem i kierunkiem Ducha Świętego, dusza nie jest przez to odsunięta od przylgnięcia i bezpośredniego zjednoczenia $z$ Najwyższym Dobrem i prostą istotą Bożą samą w sobie; przeciwnie, dusza widzi się dzięki temu pociagnięta w Bogu z większą łatwością i trwa zajęta Nim z większą stałością...

Dzieje się to doskonale wówczas, gdy dusza podlega działaniu i kierownictwu Ducha Świętego od wewnątrz i niejako samorzutnie. Doświadcza ona wtedy, że to życie dla Maryi nie jest przeszkodą do życia dla Boga, lecz przeciwnie, podporą i moca. Mówiąc jeszcze lepiej, w tym życiu maryjnym zlewa się niejako miłość Boga przez Maryję i z Maryją dla Boga, której kresem jest rozpłynięcie (zanurzenie) w miłości i spoczynek w Bogu wraz z tą najmilszą Matka. Powiedzmy jeszcze, że życie to polega na miłości, skierowanej zarazem ku naszej najmilszej Matce i ku Bogu, kresem pozostaje jednak odpoczynek w Bogu, jako ostatecznym celu"79.

Słusznie o. Jan od Jezusa Hostii OCD oceniając traktat o. Michała od św. Augustyna napisal: „Wydaje się, iż to jest najwyższy punkt, do jakiego wzniosła się nauka maryjna w Karmelu; i prawdę mówiąc, nie może się już wznieść wyżej. Dotykamy tu szczytów zastrzeżonych dla dusz całkiem zagubionych w Bogu, i nic dziwnego, że nauka tak wzniosła pozostała zamknięta w pustelni, gdzie się zrodziła. Niemniej pozostaje faktem, ze Karmel, od samego zarania cały maryjny, zachował i wzbogacił swój skarb, doprowadzając logicznie do ostatecznych wniosków to, co stanowiło całą jego rację istnienia, i to, jak wypadało, na właściwej sobie linii kontemplacyjnej i pustelniczej ${ }^{\prime 180}$.

\section{KRAKOWSKI KLASZTOR NAWIEDZENIA NMP NA PIASKU PROMOTOREM KULTU MATKI BOŻEJ W POLSCE, NA LITWIE I RUSI}

Duchowość i życie maryjne Karmelu kształtowane tradycją, normami Kapitul Generalnych oraz przepisami liturgii i doktryna wspomnianych teologów zakonu znalazły swoje odbicie i realizacje w krakowskim klasztorze. Świadczą o tym zachowane starodruki w bibliotece klasztornej wymienionych autorów, liczne miniatury w pergaminowych księgach liturgicznych z motywami maryjnymi, kompozycje malarstwa sztalugowego i freskowego, hafty i rzeźba klasztoru, księga bractwa szkaplerznego i dzieje sanktuarium Matki Boskiej Piaskowej. Wszystko to świadczy, że klasztor Karmelitów na Piasku

${ }^{79}$ Tamże, s. 189; por. P. Michael a s. Augustino O. Carm., De vita Mariae-formi..., s. 372-379; Nilo Geagea OCD, Una devozione ecumenica, La Madonna del Carmine. Roma 1990 , s. 102.

${ }^{80}$ O. Jan od Jezusa Hostii OCD, Matka..., s. 9. 
był dynamicznym ośrodkiem kultu Matki Bożej i wzorcowym modelem dla wszystkich innych klasztorów zakonu. Pozycja klasztoru z królewskiej fundacji ze stołecznego miasta stawiała go na pierwszym miejscu w hierarchicznym wykazie. I słusznie zauważył historyk tego klasztoru o. Bronisław Alfons Tomaszewski, że „dzięki swej wszechstronnej aktywności klasztor krakowski stał się dla innych konwentów na ziemiach polskich caput provinciae, fons, mater et magistra" $" 81$

Owocem życia maryjnego klasztoru była promocja kultu Matki Bożej poprzez wlaściwe karmelitańskiemu charyzmatowi apostolstwo i duszpasterstwo, a szczególnie przez Konfraternię Szkaplerza św. i sanktuarium Matki Boskiej Piaskowej.

1) We wszystkich klasztorach zakonu karmelitańskiego bractwa szkaplerzne zakładane są na mocy aktu erekcyjnego klasztoru. Przy innych kościołach zakłada je o. General Zakonu za zgoda ordynariusza miejsca. Stad klasztor krakowski nie posiadał specjalnego aktu erekcyjnego dla bractwa, którego organizacja opierała się na przepisach i wytycznych pap. Sykstusa IV z $1475 \mathrm{r}^{82}$ oraz konstytucji Klemensa VIII "Quaccumque" z dnia 7 XII $1604 \mathrm{r}^{83}$ Najwcześniejsze wzmianki o działalności bractwa pochodzą z XVII w. Wcześniejsze dokumenty uległy spaleniu. O. Marcin Charzewicz, prowincjał karmelitów w Polsce w dokumencie z 1669 r. utrzymuje, że Bractwo Szkaplerza Świętego w Krakowie, zgodnie z konstytucją Klemensa VIII zostało formalnie odnowione i potwierdzone przez prowincjała Wawrzyńca Drużynę w $1608 \mathrm{r}^{84}$ Wynika z tego, że istniało w XVI wieku. Tadeusz M. Trajdos uważa, że początki bractwa sięgają Jagiellonów. Na potwierdzenie przytacza dokument generała zakonu z $1411 \mathrm{r}$., moca którego przyjmuje rajców miasta Krakowa i pisarza Szymona do bractwa i udziału we wszystkich dobrach duchowych klasztoru w życiu i po śmierci ${ }^{85}$.

Przytoczony dokument nie świadczy wprost o przynależności radnych miasta do bractwa szkaplerznego, ale też tego nie zaprzecza. Wskazuje raczej

81 Dzieje klasztoru oo. Karmelitów na Piasku w Krakowie. Kraków 1954 (maszynopis), s. 18; Gradual karmelitański z 1644 raku o. Stanisława ze Stolca. Opr. T. Chrzanowski i T. Maciejewski. Warszawa 1976, s. 94; K. Płonka-Bałus, Antyfonarz z roku 1397 $w$ Bibliotece OO. Karmelitów na Piasku w Krakowie. Ze studiów nad iluminatorstwem czeskim przelomu XIV i XV wieku. „Folia Historiae Artium”. T. 27:1991, s. 35-60; T. M. Trajdos, Fundacja klasztoru..., s. 112.

${ }^{82}$ Bull. Carm. I, s. 318-352.

${ }^{83}$ Bull. Carm. II, s. 326-330.

${ }^{84}$ O. B. Panek O. Carm., Dzieje Bractwa Szkaplerza Swiętego przy kościele oo. Karmelitów w Krakowie na Piasku do końca XVII wieku. Roczniki Teologiczno-Kanoniczne. T. 10, z. 3 (1963), s. 43.

${ }^{85}$ T. M. Trajdos, Fundacja klasztoru..., s. 118-119. 
na duchową agregację świeckich do zakonu w typie popularnego przywileju philadelphia. Pomimo braku dokumentów należy stwierdzić, że Bractwo Szkaplerzne u Karmelitów w Krakowie było najstarszym bractwem tego typu na ziemiach polskich. Dokumenty z XVII w. opisują jego strukturę prawna i organizacyjna, zarząd, fundusze, przywileje, obowiązki i wykazy członków bractwa oraz zadania apostolskie ${ }^{86}$. W roku 1648 bractwo miało własną kaplicę i zakrystię bogato uposażone. Inwentarz wymienia 2 oltarze, 16 obrazów, 12 kielichów (w tym 6 złotych, a inne ze srebra - pozłacane), paramenty kościclne, 3 relikwiarze, choragwie itd. ${ }^{87}$. Należało do najliczniejszych i dynamicznych bractw religijnych w Krakowie.

\section{2) Sanktuarium Matki Boskiej Piaskowej ${ }^{88}$}

Sanktuarium należy do najpopularniejszych w Krakowie. Pod koniec XV w., na ścianie zewnętrznej kościoła - obok bocznego wejścia, nieznany malarz namalowal wizerunek Matki Boskiej z Dzieciatkiem Jezus na lewym ramieniu w typie hodegetrii piekarskiej, „aby przechodzący i wchodzący ludzie pokłon czyniąc Rodzicielce Bożej o Niej pamiętali" ${ }^{\prime 9}$. Cudowny obraz o wymiarach $100 \times 150 \mathrm{~cm}$, namalowany przez zakonnego malarza technika temperowa na tynku - „fresco secco", przedstawia Madonnę w dojrzałym wieku, pełną majestatu i godności, z troskliwie i czule pochyloną głową do Dzieciątka o głębokim i lagodnym spojrzeniu oczu. Wkrótce obraz zasłynąl licznymi łaskami. Do rozwoju kultu znacznie przyczyniła się królowa Bona, która w każdy czwartek i sobotę nawiedzala Matkę Bożą. Na skronie Dzieciatka i Maryi ofiarowała srebrne korony. W miejsce pierwotnej kapliczki w 1. 1637-1641 wybudowano nową, na rzucie wydłużonego prostokąta centralną kaplicę kopułową bez tamburu, zwieńczoną kolistą latarnia, z ośmioma

${ }^{86}$ B. Panek O. Carm., Dzieje Bractwa..., s. 47-55; O. Cyprian a s. Maria OCD, Skarb Karmelitański. Kraków 1650.

${ }^{87}$ Tamże, s. 58.

${ }^{88}$ Ważniejsza bibliografia: J. Duracz, Hystoria o dziwnie cudownym obrazie Błogostawionej Panny Mariey... w Krakowie na Piasku. Kraków 1610; M. Grodziński, Ogród fiolkowy karmelitański. Kraków 1673; Z. Załęski, Koronacja cudownego obrazu w kościele oo. Karmelitów na Piasku w Krakowie w dniu 8 września 1883 roku. Kraków 1883; J. Rogalski, Kościól na Piasku. Kraków 1863; S. Tomkiewicz, Kaplica N. P. Maryi na Piasku. W: Kalendarz Krakowski 1899; J. Bieniarzówna, A. T. Piotrowski, Sanktuarium Maryjne w Kościele oo. Karmelitów na Piasku w Krakowie. Kraków 1983; Wacław z Sulgostowa (E. Nowakowski), O cudownym obrazie Matki Bozej w Karmelu Krakowskim na Piasku. Kraków 1898.

${ }^{89}$ J. Duracz, Hystoria o dziwnie cudownym obrazie..., s. 5-6. 
okienkami. Centralna część kaplicy z prezbiterium na rzucie kwadratu poszerzona i wzbogacona została o dwa boczne aneksy na wspólnej osi części centralnej kaplicy. Dzieje kultu obrazu, historię budowy i jej opis oraz jej treści artystyczne i założenia ideowe zostały szczegółowo ukazane w naukowej rozprawie Janiny Bieniarzówny i Antoniego Tomasza Piotrowskiego ${ }^{90}$.

Podkreślić należy, że uroczystość Nawiedzenia NMP ściaga mieszkańców Krakowa i liczne pielgrzymki z okolicy na odpust od XVI wieku. Piotr Hyacynt Pruszcz w swoim przewodniku podaje, że na odpust i oktawę przybywa do tego sanktuarium 130000 wiernych, przystępujących do Sakramentów świętych ${ }^{91}$. Sanktuarium wielokrotnie nawiedzane było przez króla Władysława IV i Jana III Sobieskiego. Dla zapewnienia pielgrzymom odpowiedniej katechezy klasztor posiadał kaznodzieję zwyczajnego i nadzwyczajnego oraz w języku niemieckim, którzy głosili kazania szczególnie w uroczystości odpustowe Matki Bożej Szkaplerznej i Nawiedzenia NMP wraz z nowennami i oktawami tych świąt. Liczne łaski i cuda Matki Boskiej Piaskowej stwierdzone przez biskupia komisję zaowocowały dekretem Kapituły Watykańskiej z dnia 7 maja 1764 r., zezwalającym na koronację cudownego obrazu. Pomimo bliższych przygotowan do koronacji nie doszło z przyczyn politycznych i braku pieniędzy na nowe korony ${ }^{92}$. Koronacja odbyla się dopiero 8 września 1883 r. Dokonał jej bp Albin Dunajewski w obecności 150000 wiernych z całej Polski, w dwusetną rocznicę wiktorii wiedeńskiej przez króla Jana III Sobieskiego, który przed odsieczą nawiedzil Sanktuarium Matki Boskiej Piaskowej. Korony według projektu Jana Matejki wykonał złotnik krakowski Władysław Glixelli' ${ }^{93}$.

3) Wpływ krakowskiego klasztoru na rozwój kultu Matki Bożej w Polsce, na Litwie i Rusi

Po ukończeniu budowy kościoła i klasztoru na Piasku, karmelici zjednali sobie w Polsce wielkie uznanie i przychylność społeczeństwa. Dowodem tego jest powstanie 72 fundacji w czterech prowincjach ${ }^{94}$. Na czele ich - pisał

${ }^{90}$ Sanktuarium Maryjne w Kościele oo. Karmelitów na Piasku w Krakowie. Dzieje kultu i kaplicy. Kraków 1983.

${ }^{91}$ Stolecznego miasta Krakowa kościoły i klejnoty. Kraków 1647, s. 65.

${ }^{92}$ J. Bieniarzówna, A. T. Piotrowski, Sanktuarium Maryjne..., s. 70.

${ }^{93}$ Tamże, s. 74-79.

${ }^{94}$ J. M. Giżycki (Wołyniak), Z przesztości Karmelitów na Litwie i Rusi, cz. 2. Kraków 1918 , s. 34 . 
o. Wacław Nowakowski - „stał zawsze na straży klasztor krakowski, sławny wielką liczbą zakonników (bywało ich tutaj do 70), pobożnych i gorliwych o wiarę i naukowo w akademii krakowskiej wykształconych, najściślej wypełniających swoją regułę. Grodzieński („Ogród frołkowy” s. 10) powiada: „Konwent krakowski Karmelitów miał wielu nader dostojnych mężów świątobliwością i nauką chwalebnych". Z powodu zaś cudownego obrazu Matki Bożej i uroczystych przy tym nabożeństw [...] pociagal do siebie wszystkich nie tylko mieszkańców Krakowa, lecz i z najdalszych stron przybywających czcicieli Matki Bożej. Królowie polscy, biskupi, senatorowie spieszyli tu, u podnóża cudownego obrazu szukać dla siebie, dla swoich rodzin i dla Ojczyzny opieki i ratunku i ofiarami hojnymi świadczyli o wdzięczności za otrzymane laski' ${ }^{\prime 95}$. Z tego też powodu powstawały nowe fundacje, które rozwijały u siebie kult Matki Bożej. Do najważniejszych należały sanktuaria:

a) Białynicze na Białorusi w dawnym powiecie orszańskim

W klasztorze ufundowanym przez księcia Leona Sapiechę, wojewodę wileńskiego i hetmana wielkiego litewskiego, jako wotum wdzięczności za zwycięstwo nad Moskwą w 1618 r. dla oo. Karmelitów, zasłynął laskami obraz Matki Boskiej w typie zbliżonym do hodogetrii, z berłem w ręku i globusem w lewej ręce Dzieciątka Jezus. Madonna swym pięknem, dobrocia, skupieniem i przenikliwym spojrzeniem pelnym miłosierdzia, przyciagała wiernych do siebie i budzila nadzieję i olśnienie. Karmelici rozwijali Jej kult podobnie jak w Krakowie. W 1655 r. w obawie przed wojskami Rosji przeniesiono obraz do fortecy w Lachowiczach, gdzie pozostal przez 100 lat otaczany wielka czcia. Dopiero po wybudowaniu nowego kościoła w Białyniczach Karmelici przy pomocy księżnej Teofili Sapieżyny z Jabłonowskich, wojewodzianki nowogrodzkiej, uroczyście przenieśli wizerunek do swego kościoła. Z powodu licznych lask, stwierdzonych przez komisję biskupia, papież Benedykt XIV wyraził zgodę na koronację obrazu. Dokonał jej bp smoleński Jerzy Mikołaj Hylzen dnia 29 IX $1761 \mathrm{r}^{96}$ Sanktuarium promieniowało na całą okolicę i przyciagało licznych pielgrzymów. Karmelici w swoim klasztorze mieli drukarnię, zespól muzyków (orkiestrę) i prowadzili studia filozoficzne dla młodzieży zakonnej ${ }^{97}$. Po powstaniu listopadowym w 1832 r. zaborcze

${ }^{95} \mathrm{O}$. Waclaw z Sulgostowa, O cudownym obrazie..., w krakowskim..., s. 7-8.

96 Tenże, O cudownym obrazie Matki Bożej w kościele oo. Karmelitów w Bialyniczach. Kraków 1899, s. 13; tenże, O cudownych obrazach w Polsce Przenajśw. Matki Bożej. Kraków 1902, s. 39.

${ }^{97}$ Tamże, s. 4. 
władze Rosji zamknęły klasztor, a kościól przekazano duchowieństwu diecezjalnemu. W roku zaś 1876 władze carskie zabrały katolikom kościól w Białyniczach i przekazały go prawosławnej cerkwi ${ }^{98}$.

b) Bołszowce w diecezji lwowskiej, w dawnym powiecie rohatyńskim

Marcin Kazanowski, kasztelan halicki, a następnie wojewoda podolski i hetman polny koronny, przeprawiając się promem przez Dniestr w pościgu za Tatarami (1624?) wyłowił z rzeki rulonik z obrazem Matki Bożej. Po odniesionym zwycięstwie przed tym obrazem odprawił dziękczynne nabożeństwo. Następnie w swoich dobrach w Bołszowcu wystawił drewniany kościół pod wezwaniem Zwiastowania NMP oraz klasztor dla oo. karmelitów. W XVII w. staraniem Jana Gałeckiego i jego żony Teresy oraz Antoniego Jabłonowskiego, wojewody poznańskiego, wzniesiono i wyposażono murowany kościół. Po zbadaniu wszystkich lask arcbp Waclaw Sierakowski ogłosil obraz Matki Bożej za cudowny. Na mocy dekretu Stolicy Apostolskiej z dnia 12 maja 1769 r. Kryspin Cieszkowski, sufragan lwowski, w dniu 15 sierpnia $1777 \mathrm{r}$. ukoronowal obraz koronami papieskimi. W czasie I wojny światowej kościół i klasztor uległ częściowemu zniszczeniu, karmelici przenieśli obraz do Lwowa. Po II wojnie światowej znów go przewieziono, ale tym razem do Krakowa na Piasek, a od 1966 roku do kościoła oo. Karmelitów w Gdańsku.

Obraz namalowany techniką olejną na plótnie naklejonym na sosnową deskę o wymiarach $83 \times 102 \mathrm{~cm}$, jest kopią Madonny z Dzieciątkiem pod jabłonią, Łukasza Cranacha starszego. Oryginał z XV w. znajduje się w Ermitażu w Sankt Petersburgu. Kopia z I poł. XVIII w. przedstawia Madonnę tronująca $w$ typie zbliżonym do Nikopoja, z Dzieciątkiem stojącym na Jej kolanach. Obie postacie znajdują się pod baldachimem, Maryja przedstawiona jest jako wspólodkupicielka ${ }^{99}$.

c) Obory w Ziemi Dobrzyńskiej, w diecezji płockiej

W 1605 r. dziedzic wioski Łukasz z Muszynowa Rudzowski z żoną Anną z Galemskich, ufundowal na górze zw. Grodzisko klasztor dla Karmelitów Trzewiczkowych, którzy tu przybyli z Bydgoszczy. Na nową fundację przy-

${ }^{98}$ S. M. Grażyna od Wszechpośrednictwa M. B. i S. M. Gizela od Niep. Serca Maryi, Z dawna Polski Tyś Królowa - Koronowane wizerunki Matki Bożej 1717-1990. Szymanów 1990 , s. 84.

${ }^{99}$ O. Wacław z Sulgostowa (Nowakowski), O cudownych obrazach w Polsce, s. 5758; S. M. Grażyna od Wszechpośrednictwa... i S. M. Gizela od Niepok. S. M., Z dawna Polski Tyś Królowq, s. 106; A. Fridrich SJ, Historye cudownych obrazow Najśw. Maryi Panny w Polsce. T. 2. Kraków 1904, s. 162-165. 
wieźli ze sobą Pietę - statuę Matki Bożej Bolesnej, już jako laskami słynąca w Bydgoszczy. Kościół murowany wzniesiono w 1642 r. a klasztor dopiero w $1741 \mathrm{r}$.

Gotycka Pieta, rzeźbiona w drzewie lipowym przez nieznanego artystę z przelomu XIV/XV w., polichromowana ma $64 \mathrm{~cm}$ wysokości. W klasztorze bydgoskim, wstawiennictwu Matki Boskiej Bolesnej przypisywano w 1. 1581-1593 siedem cudów. Od 1627 r. Matka Boża odbiera kult w Oborach, jako patronka Ziemi Dobrzyńskiej, miejsce pielgrzymowania Ludu Bożego. Z powodu licznych łask w 1747 r. rozpoczęto starania o koronację Piety. W 1761 r. komisja biskupia stwierdziła i udokumentowala 78 rask i cudów. W czasie hitlerowskiej okupacji Niemcy zamknęli kościół, a zakonników wywieźli do obozu koncentracyjnego. Statuę Matki Bożej ukrył rolnik Fabiański ze Stalmierza. W 1945 r. karmelici ponownie objęli klasztor, uroczyście otwarto kościół zamknięty przez cały czas wojny i w uroczystej procesji wniesiono cudowną figurę do świątyni. W latach 1970 ponownie podjęto starania o ukoronowanie figury. Na mocy Breve Apostolskiego z 7 X $1974 \mathrm{r}$. papież Paweł VI zezwolił na ukoronowanie cudownej Piety. Koronacja odbyła się 18 lipca 1976 r. Dokonał jej ks. kard. Stefan Wyszyński, prymas Polski, przy udziale 9 biskupów, licznego duchowieństwa i ponad 20 tysięcy pielgrzymów - czcicieli Matki Boskiej Bolesnej ${ }^{100}$.

\section{d) Wola Gułowska, kościól Narodzenia NMP w diecezji siedleckiej}

Według o. Wacława Nowakowskiego ${ }^{101}$ we wsi Gułowska Wola objawiła się w roku 1548 Matka Boża Jadwidze, kobiecie modlacej się przed figurą Ukrzyżowanego Chrystusa. Z tego powodu dziedzic miejsca Hieronim Rusiecki, chorąży sandomierski, wystawił na tym micjscu kaplicę, do której jego żona Katarzyna Krasicka oddała obraz Matki Bożej, który nabyła od wieśniaka ze wsi Przytoczna. Wieśniak znalazł obraz wyrzucony do błota w miasteczku Lysobyki (dziś Jeziorzany) przez Kalwinów. W roku 1633 Ludwik Kracicki, kasztelan ciechanowski, dokonal fundacji klasztoru oo. Karmelitów i sprowadził zakonników z krakowskiego klasztoru na Piasku. Rozwinęli oni kult Matki Bożej wznosząc $z$ ofiar dobrodziejów nową świątynię, konsekrowana przez bpa Jana Kantego Lenczewskiego, sufragana i oficjała lubelskiego

${ }^{100}$ O. Wacław z Sulgostowa, O cudownych obrazach w Polsce, s. 474-475; A. Fridrich SJ, Historye cudownych obrazów Najśw. Maryi Panny w Polsce. T. 3, s. 115-120; ks. W. Gapinski, Koronacja cudownej figury Matki Bozej Bolesnej w Oborach. „Miesięcznik Pasterski Plocki”, nr 12:1976, s. 453-476; M. Krajewski, o. M. Wojnarowski OC, Kosciól i klasztor Ojców Karmelitów w Oborach. Obory 1986; S. M. Grażyna od Wszechpośrednictwa... i S. M. Gizela, Z dawna Polski Tyś Królowa, s. 387-389.

${ }^{101}$ O. Wacław z Sulgostowa, O cudownych obrazach w Polsce, s. 195. 
w 1782 r. karmelici założyli tutaj nowicjat. Klasztor został skasowany ukazem carskim w 1864 r. Duszpasterstwo przejęło duchowieństwo diecezjalne. Po wywiezieniu z Kodnia cudownego obrazu do Częstochowy, Matka Boska z Woli Gułowskiej stała się jedynym miejscem pielgrzymowania Ludu Bożego w diecezji podlaskiej. W 1924 r. ks. bp Henryk Przeździecki, ordynariusz podlaski, oddał z powrotem pod opiekę zakonu Karmelitów sanktuarium Matki Bożej w Woli Gułowskiej. Pierwszym przeorem i proboszczem odzyskanego klasztoru był o. Rajmund Goląka, a po nim o. Gabriel Wielgus. Odnowiony kościół i klasztor uległy poważnemu zniszczeniu w czasie kampanii wrześniowej 1939 r. W dniach 4 i 5 października pod Kockiem została stoczona ostatnia, najbardziej krwawa bitwa o klasztor i sanktuarium wojska polskiego z najeźdźca germańskim. Samodziclna grupa operacyjna "Polesie" dowodzona przez gen. Franciszka Kleeberga utrzymywała swą pozycję aż do złożenia broni z powodu braku amunicji. Zacięta walka toczyła się na placu i cmentarzu przykościelnym, na którym pogrzebano ok. 200 żołnierzy polskich. Odtąd corocznic w rocznicę bitwy żyjący „kleeberczycy” przybywają na mogiły kolegów i do swej Patronki w Woli Gułowskiej. Po przeprowadzeniu generalnego remontu sanktuarium podjęto starania w Rzymie o ukoronowanie cudownego wizerunku. W odpowiedzi na złożoną dokumentację o kulcie i laskach Matki Bożej, Stolica Apostolska wydala dekret zezwalający na koronację obrazu papieskimi koronami z datą 9 listopada $1981 \mathrm{r}$. i pod pieczęcia Rybaka. Koronacji dokonał ks. arbp Józef Glemp, prymas Polski, dnia 5 IX 1982 r., przy udziale 16 biskupów, licznego duchowieństwa oraz ok. 100000 wiernych $^{102}$.

Obraz nieznanego malarza, namalowany na desce lipowej o wymiarach $85 \times 122 \mathrm{~cm}$, pochodzi z XVI w. Przedstawia Madonnę w półpostaci z Dzieciątkiem Jezus na lewym ramieniu $w$ typie hodegetrii $z$ jabłkiem w prawej dłoni. Jawi się jako Przewodniczka, ukazująca nam Syna Bożego, jedyną Drogę, Prawdę i Życie.

e) Inne obrazy Matki Bożej laskami stynące - nie koronowane ${ }^{103}$

Oprócz wymienionych wyżej sanktuariów maryjnych prawie we wszystkich klasztorach były laskami słynące obrazy Matki Bożej, wokół których

102 Z. Walczy, Sanktuarium Maryjne w Woli Gulowskiej. „Nasza Przeszłość”. T. 60:1983, s. 129-168; S. M. Grażyna i S. M. Gizela, Z dawna Polski Tyś Królowq, s. 426428; A. Fridrich SJ, Historye cudownych obrazów, t. 3, s. 384-387.

${ }^{103}$ Por. o. Wacław z Sulgostowa, O cudownych obrazach w Polsce, s. 204, 253, 259, 378, 401, 542, 590, 703, 740; M. Krajewski, Sanktuarium Matki Bozej Pocieszenia w kościele Ojców Karmelitów w Pilźnie. Pilzno 1995. 
koncentrował się kult Matki Boskiej Szkaplerznej. Większość tych obrazów przyozdobiona została w XVIII w. srebrnymi sukienkami, trybowanymi i koronami, prywatnie nakładanymi na skronie Dzieciątka i Madonny. Do głośniejszych należały obrazy Madonny w klasztorach: Horodyszcze na Wołyniu, Kcynia - obraz MB Laskawej, Kochawina w diecezji lwowskiej, Lublin kopia Matki Bożej Piaskowej, Lwów - kościół św. Michała, Poznań - kościół Bożego Ciała z obrazcm hodogetrii częstochowskiej, Sąsiadowice w diecezji przemyskiej, Warszawa na Lesznie, Wilno - obraz Matki Boskiej Anielskiej w kościele Wszystkich Świętych.

Do obrazów nie koronowanych należy wymienić łaskami słynący obraz Matki Bożej Pocieszenia z Jej sanktuarium w Pilźnie w dawnym klasztorze oo. Augustianów, fundowanym przez Króla Władysława Jagiełłę (3 III 1403), a od 1841 r. zamieszkałym przez oo. karmelitów. Matka Boża Pilzneńska ratowała mieszkańców miasta przed inwazjami wrogów, epidemiami, klęskami. Kronika rodu Tarnowskich przekazała, że do Pilzna przybył król Władysław Jagiełło ze swoja żona Jadwig̨, którzy zawiesili swoje herby królewskie Orła i Pogoni po obu stronach wizerunku Matki Boskiej. Klasztor wraz z miastem uległ zniszczeniu i spaleniu przez wojska Rakoczego (18 III 1657). W $1665 \mathrm{r}$. miejscowy malarz odtworzył z pamięci i na podstawie ikonografii obraz Matki Boskiej Pilzneńskiej, przy którym oo. augustianie złożyli Arcybractwo Paska Najświętszej Maryi Panny Matki Pocieszenia, a oo. karmelici Bractwo Matki Bożej Szkaplerznej. W kaplicy Matki Bożej pocieszenia wokól ołtarza zgromadzone są liczne wota, tablice pamiątkowe świadczące o wdzięczności za uzyskane laski i o wielkim patriotyzmic mieszkańców miasta i okolicy.

Geografia karmelitańskich sanktuariów w Polsce ksztaltowana była administracyjnym podziałem na prowincje. Każda prowincja miała swoje centralne sanktuarium Matki Bożej. Dla Małopolskiej Prowincji była Matka Boska Piaskowa w Krakowie; dla Litewskiej p.w. św. Jerzego - Białynicze; dla Ruskiej p.w. św. Józefa - Bołszowce i dla Wielkopolskiej - Obory w ziemi dobrzyńskiej.

\section{ROLA SANKTUARIÓW W KSZTAŁTOWANIU ŻYCIA RELIGIJNEGO}

Maryjne sanktuarium jest domem naszej Matki i Królowej - szkoła kształtowania wiary, kultury i ducha narodu. Sanktuarium, to miejsce święte obecności Pana i przystań pielgrzymującego i pokutującego Ludu Bożego. Celem i zadaniem jego jest cześć i adoracja Boga, wyznawanie wiary, liturgiczne sprawowanie zbawczych tajemnic Chrystusa oraz modlitwa wspólno- 
towa i osobista. Każde sanktuarium, podobnie jak każdy kościół, jest ikona przebywania Boga pośród ludzi we wspólnocie kościelnej, ikoną każdego ucznia Chrystusa, będącego świątynią Ducha.

Takie znaczenie ma sanktuarium maryjne. W nim Maryja odbiera cześć od wiernych ze względu na tajemnicę Wcielenia, jako Dom Boży, Stolica Mądrości, żywa Świątynia Ducha Świętego i tak w sposób konkretny jest uprzywilejowaną droga wiodaca na spotkanie $z$ Panem ${ }^{104}$.

Maryja jest najwznioślejszym wzorem w kształtowaniu życia religijnego przez wiarę, miłość, nadzieję i całkowite oddanie się Bogu. „Kościół w osobie Najświętszej Maryi Panny już osiaga doskonałość, dzięki której istnicje nieskalany i bez zmazy” - równocześnie zaś „chrześcijanie ciagle jeszcze staraja się usilnie o to, aby przezwyciężając grzech, wzrastać w świętości; dlatego wznosza oczy ku Maryi, która świeci calej wspólnocie wybranych jako wzór cnót" ${ }^{\text {"105. }}$. Maryja po zakończeniu doczesnego pielgrzymowania uczestniczy już w szczęściu i chwale swego Syna, zasiadającego po prawicy Ojca. Ale dla wszystkich ludzi na ziemi jest Ona "Gwiazda przewodnia" w doczesnym pielgrzymowaniu. „Jeśli wznoszą oni ku Niej oczy na różnych miejscach ziemskiego bytowania, to dlatego, że „zrodziła Syna, którego Bóg ustanowił pierworodnym między wiclu braćmi $(\mathrm{Rz} 8,29)$, a także dlatego, iż w zrodzeniu i wychowywaniu tychże braci i sióstr Maryja „współdziałała swą macierzyńską miłością"106. Każdego pielgrzyma prowadzi do Chrystusa, ukazuje drogę do Niego i mówi: „Zróbcie wszystko cokolwiek wam powie” $(\mathrm{J} 2,5)$.

Kształtowanie życia religijnego $\mathrm{w}$ sanktuariach dokonuje się przez zapewnienie wiernym środków zbawienia ,przez gorliwe głoszenie Słowa Bożego, przez odpowiednie ożywienie życia liturgicznego, zwłaszcza przez sprawowanie Eucharystii i pokuty oraz przez kultywowanie zatwierdzonych form pobożności ludowej" (kan. 1234).

\section{Pielgrzymowanie}

Pielgrzymka jest formą kultu ściśle związaną z życiem każdego sanktuarium. Zjawisko pielgrzymowania jest powszechnym i interesujacym zagadnieniem. Potwicrdza nicjako biblijny fakt upadku czlowicka i wygnania go z raju, że czlowiek na ziemi jest ostatecznie tulaczem, znajduje się poza szczęściem ojcowskiego domu i bezwiednie szuka drogi, by powrócić do niego. Początki historii zbawienia Pismo święte wiąże z „wyjściem” i opuszczeniem

\footnotetext{
${ }^{104}$ Cosilium Primarium Anno Mariali celebrando 1987

${ }^{105}$ Sobór Watykański II. Konstytucja dogmatyczna o Kościele Lumen Gentium, 65.

${ }^{106}$ Jan Pawel II, Redemptoris Mater. Watykan 1987, s. 12.
} 
dotychczasowego trybu życia i udaniem się tam, gdzie Bóg woła. Przykładem jest powołanic Abrahama i wyjście z niewoli egipskiej. Również życie Maryi było pielgrzymowaniem. Nauka Kościola i liturgia ukazuja życie ziemskie jako pielgrzymkę, a wstawicnnictwo Matki Bożej wobec swoich dzieci jako pomoc i opiekę podczas doczesnego pielgrzymowania do niebieskiego sanktuarium. Pielgrzymki mają wielką wartość formacyjną, o ile są dobrze przygotowane od strony organizacyjnej i liturgicznej. Sa wędrownymi rekolekcjami w ustawicznej modlitwie, pokucie, świadczeniu milości przez okazywanie bliźnim pomocy i wyrozumiałości.

\section{Sakrament Pokuty i Eucharystii}

Najważniejszym środkiem kształtowania życia religijnego i dążenia do doskonałości są te dwa sakramenty, dające i umacniające życie łaski. Przybywający do sanktuarium pielgrzymi klękają w poczuciu winy, stają w prawdzie przed Bogiem, dokonują rozliczenia, nawracają się, doświadczają tajemnicy miłosierdzia. Pielgrzymka związana jest z pokuta, niewygoda, postem, umęczeniem drogą i aurą. Powodem pielgrzymowania jest potrzeba wewnętrznego wyzwolenia umysłu i serca, ciała i duszy z niewoli osobistych grzechów i od wszelkiego zła moralnego. Klękanie dla uwielbienia Boga i z powodu własnych win, w poczuciu żalu, z pragnieniem i prośbą odpuszczenia grzechów jest autentycznym świadectwem wiary. Dzięki obecności Maryi i Jej wstawiennictwu, ludzie uświadamiaja sobie potrzebę nawrócenia i powracaja przez Nią do Boga ${ }^{107}$

Sprawowanie Eucharystii jest szczytem i fundamentem całej działalności duszpasterskiej sanktuariów. Ojciec Święty Jan Paweł II szczególnie uwydatnił rolę Maryi w odniesieniu do Eucharystii: „Pobożność ludu chrześcijańskiego zawsze dostrzegala głęboką więź pomiędzy nabożeństwem do Matki Bożej i kultem Eucharystii. Związek, który wynika z samej rzeczywistości Wcielenia Słowa i z niezastapionej roli w ekonomii zbawienia przez Maryje, która zrodzila Pana i ofiarowała Go ludziom. W Eucharystii uaktywnia się pamięć Męki Pańskiej, urzeczywistnia się komunia świętych, pośród których pierwsza jest Maryja Dziewica; za sprawą Ducha Świętego realizuje się Kościół w komunii ze zmartwychwstałym Chrystusem"108.

${ }^{107}$ B. J. Wanat, Rola sanktuariów maryjnych archidiecezji krakowskiej w ksztaltowaniu życia religijnego. Materialy duszpasterskie, z. 22. Kraków 1988, s. 19.

${ }^{108}$ Consilium Primarium Anno Mariali celebrando 1987 (instrukcja Stolicy Apostolskiej na rok Maryjny 1987). 


\section{Głoszenie Słowa Bożego}

Sanktuaria są miejscami, w których głosi się Słowo Boże, a nauczanie katechetyczne stanowi jedna $z$ istotnych powinności, w duchu i sposobie nowej ewangelizacji, zrozumiałej dla współczesnego człowieka. Papież Jan Paweł II w encyklice „Redemptoris Mater” przypomnial, że Synod nadzwyczajny z 1986 r. wezwal wszystkich do tego, ażeby wiernie podążali za nauka i wskazaniami Soboru oraz „aby w roku maryjnym ponownie odczytali i pogłębili naukę Soboru o Bogarodzicy Dziewicy obecnej w tajemnicy Chrystusa i Kościoła"109. Papież daje nam teologiczny wykład roli Maryi w życiu Chrystusa i Jego zbawczej misji. Należy ukazać Maryje, że od wieków powolana na Matkę Odkupiciela, pelna łaski, wprowadzona w dzielo zbawcze jako Matka Bożego Syna i Socia Christi, a przez to szafarka i pośredniczka lask, jest obecna w tajemnicy dokonującego się wcielenia odkupieńczego.

Kicdy mówimy o antropologicznym aspekcie dzialalności duszpasterstwa maryjnego, akcentujemy człowieczeństwo Maryi. W katechezie trzeba ukazywać Maryję jako pcłną łaski, najświętszą istotę, arcydzicło Trójcy Przenajświętszej, ale również jako doskonałego człowieka, żyjącego zwyczajnie, wypełniającego codzienne obowiązi w rodzinie nazaretańskiej.

Oprócz duszpasterstwa ogólnego, karmelitańskie sanktuaria ukazuja duchowość maryjną Karmelu, pogłębioną wartość nabożeństwa szkaplerznego, wypływajacego z macierzyńskiego pośrednictwa Maryi. Realizują również program Matki Boskiej Fatimskiej. Ponadto nastawiają się na duszpasterstwo specjalistyczne, wypływające z karmelitańskiego charyzmatu. Prowadzą działalność formacyjną młodzieży i dzialalność charytatywna.

\section{Działalność kulturalna}

Sanktuarium maryjne jest nie tylko miejscem modlitwy, ale stanowi również ośrodek kulturalny, który winien wywierać korzystny wpływ na pielgrzymów. Piękno i bogactwo architektury, stylowe wyposażenie wnętrz, nagromadzone pamiatki historyczne i ich ekspozycje, stanowią czynnik kulturotwórczy sanktuarium. Karmelitańskie sanktuaria były oazami życia wiary, kultury i oświaty. Świadczą o tym dzieje sanktuarium w Krakowie i Białyniczach związane z działalnościa formacyjna - jako seminaria zakonne; wydawniczą z własną drukarnią. Większość sanktuariów i klasztorów prowadziła szkoły podejmując działalność oświatowa.

${ }^{109}$ Jan Paweł II, Redemptoris Mater, nr 48. 
Obecne czasy stawiaja sanktuarium nowe wymagania. Powinny one stać się w sposób naturalny ośrodkami katechezy i formacji mariologicznej, dzięki wszystkim dostępnym środkom, mogacym wzbogacić doktrynalnie pielgrzymów poprzez posługę słowa, kongresy i kursy naukowe, konferencje specjalistyczne, wyposażone w dzieła z dziedziny mariologicznej biblioteki, wlaściwe czasopisma, pomoce audiowizualne (filmy, wideo), imprezy artystyczne i poetyckie, przedstawienia o tematyce religijnej, koncerty, wystawy.

Do tych wszystkich czynników kształtujących życie religijne i kulturowe dołącza się jeszcze wymiar patriotyczny kultu maryjnego, poprzez podkreślanie społecznego i narodowego charakteru kultu obecności Maryi w życiu narodu, urzędowej elekcji na Królowę Polski i wielokrotnego składania ślubów jasnogórskich oraz zawierzenia Jej Kościola i Narodu w najważniejszych momentach dziejów Ojczyzny. Wszystko to stanowi wielkie dziedzictwo duchowe narodu, dogłębnie związanego z Maryją.

Kończąc należy stwierdzić, że Klasztor oo. karmelitów na Piasku w Krakowie w ciagu 600 lat swego istnienia byl dynamicznym ośrodkiem Kultu Matki Bożej i jego promotorem w naszej Ojczyźnie, szczególnie poprzez działalność wymienionych Sanktuariów i Konfraterni Szkaplerznych. 